\title{
Phenotypic and molecular characterization of six Sudanese camel breeds
}

\author{
I.A. Ishag ${ }^{1 \#}$, M. Reissmann ${ }^{2}$, K.J. Peters ${ }^{3}$, L.M-A. Musa ${ }^{4}$ and M-K.A. Ahmed ${ }^{4}$ \\ ${ }^{1}$ Department of Animal Production, Faculty of Agriculture, University of Sinnar, Sudan \\ ${ }^{2}$ Department of Breeding Biology and Molecular Genetics, Faculty of Agriculture and Horticulture, Humboldt \\ University of Berlin, Germany \\ ${ }^{3}$ Department of Animal Breeding in the Tropics and Subtropics, Faculty of Agriculture and Horticulture, Humboldt \\ University of Berlin, Germany \\ ${ }^{4}$ Department of Genetics \& Animal Breeding, Faculty of Animal Production, University of Khartoum, Sudan
}

\begin{abstract}
The objective of this study was to sequence the growth hormone $(G H)$ gene in Sudanese camel breeds (Kenani, Lahwee, Rashaidi, Anafi, Bishari and Kabbashi) searching for single nucleotide polymorphisms (SNPs) and contribute to the phenotypic characterization of the multitude of camel ecotypes in Sudan. This will also afford the chance of investigating the possibility of the presence of correlations between body measurements and SNPs of GH gene. A length of $1732 \mathrm{bp}$, spanning the region between -44 bp upstream of the first exon and $+37 \mathrm{bp}$ downstream of the last exon was sequenced in two animals from each breed. The sequence comparison of Sudanese camel GH sequences with the GenBank sequence identified one single nucleotide polymorphism (SNP). The SNP was detected in the non coding region (intron 1) in position AJ575419:g.419C>T. A PCR-RFLP method was used to genotype 181 animals representing the six tested Sudanese breeds for detected SNP. The Bishari and Anafi breeds that are classified as riding camels had slightly higher $\mathrm{T}$ allele frequencies ( 0.57 and 0.48 , respectively) than those of the other four breeds which are classified as pack camels. The effect of genotype with regard to the SNP g.419C $>$ T on those traits was not significant.
\end{abstract}

Keywords: Camels, Sudan, growth hormone, polymorphisms, body measurements

${ }^{\#}$ Corresponding author. E-mail: abu_elharith2006@yahoo.com

\section{Introduction}

Camels provide mankind with a range of products and services, e.g. wool, meat, milk and draught power. They have been domesticated about 3000 years ago and are present in high numbers in the arid parts of Africa (ca. 11.5 million animals in this region in 1992), particularly in the arid lowlands of eastern Africa (Somalia, Sudan, Ethiopia, Kenya and Djibouti) (Schwartz \& Dioli, 1992). Sudan is rated second in numbers of camel population in the world after Somalia with an estimation of 4078 thousand head (Ministry of Animal Resources, 2006), concentrated in two main regions; the Eastern states (Butana plain and Red Sea mountains) and Western regions (Darfour and Kordofan) (Agab, 1993). The camel ecotypes in Sudan serve numerous functions in their respective production systems (e.g. milk, meat, racing, riding, packing) and are bred and selected for sustainable performance.

Phenotypic and genetic characterization to assess the existing biodiversity and differences among the Sudanese camel ecotypes is an essential prerequisite to facilitate the conservation and utilization programme in an effective and meaningful way. However, the Sudanese camel ecotypes are not well classified or defined, with very limited information available. The development in molecular genetic techniques has made it possible to identify differences between individuals at the DNA level. Recently, genetic polymorphisms at candidate genes affecting economic traits have stimulated substantial research interest because of their impending utilization as an aid to genetic selection and to demarcate evolutionary relationships in different livestock breeds (Sodhi et al., 2007). Association of several polymorphic sites (SNPs) in different candidate genes with economic traits has been much investigated in different animal species. Work based on characterization of candidate genes and their association with animal performance in camels is meagre compared with cattle (Lucy et al., 1991; Schlee et al., 1994; Ge et al., 2003), sheep (Wallis et al., 1998; Bastos et al., 2001) or goats (Wallis et al., 1998; Neelam Gupta et al., 2007). 
In farm animals, promising candidate genes for many traits are in the growth hormone axis. The growth hormone is a polypeptide hormone with diverse biological activities including somatogenic (growth promoting), lactogenic, insulin-like and diabetogenic effects. The camel growth hormone (GH) gene extends over about $1900 \mathrm{bp}$, and like other mammalian GH genes; it splits into 5 exons and 4 introns (Maniou et al., 2001).

There is no direct evidence of a correlation between body measurements and growth hormone in camels. However, Liu, et al. (2010) studied the correlation between GDF5 gene and body measurement in cattle, Ardiyanti, et al. (2009) investigated the association of GH gene and carcass traits in cattle, while Hua, et al. (2009) estimated the correlation between $G H$ gene and growth traits in goats.

The aim of this study was to sequence the growth hormone $(G H)$ gene in Sudanese camel breeds searching for single nucleotide polymorphisms (SNPs) and contribute to the phenotypic characterization of the multitude of camel ecotypes in Sudan. This will also afford the chance of investigating the possibility of the presence of correlations between body measurements and SNPs of the GH gene.

\section{Materials and Methods}

Hair samples were obtained from 181 unrelated individuals of Sudanese camels. Thirty one hair samples were collected from the Kenani breed and 30 hair samples from each of the Rashaidi, Lahwee, Anafi, Bishari and Kabbashi breeds. Genomic DNA was extracted from hair roots by using the Nucleospin ${ }^{\circledR}$ tissue kit (Macherey-Nagel), following manufacturer instructions. DNA concentration was measured with a NanoDrop spectrophotometer (Thermo Fisher Scientific Inc).

Based on the published nucleotide sequence information of the camel GH gene (GenBank accession no. AJ575419, Maniou et al., 2004) primer pairs were designed to amplify four $G H$ fragments (Kgh1b, Kgh1, Kgh2 and Kgh3) by using primer 3 programme (http://biotools.umassmed.edu/bioapps/primer3_www.cgi). The gene from -44 bp upstream of the first exon to $+37 \mathrm{bp}$ downstream of the last exon was analyzed. The primer sequences, location and size of the amplified fragments are shown in Table (1). PCR was performed in a reaction volume of $25 \mu \mathrm{L}$ using $100 \mathrm{ng}$ of DNA, $0.2 \mathrm{mM}$ of each primer, 1X PCR buffer, $2.5 \mathrm{mM} \mathrm{MgCl}_{2}, 0.2 \mathrm{mM}$ of each dNTP and 0.5 units of GoTaq flexi-DNA polymerase (Promega).

The amplification programmes consisted of 37 cycles. The first one was characterised by denaturation at $94{ }^{\circ} \mathrm{C}$ for $2 \mathrm{~min}$, annealing with the special primer temperature (Table 1) for $30 \mathrm{~s}$ and an extension step at $72{ }^{\circ} \mathrm{C}$ for $40 \mathrm{~s}$. The next 36 cycles involved a denaturation step at $94{ }^{\circ} \mathrm{C}$ for $1 \mathrm{~min}$, annealing at 51 to $57^{\circ} \mathrm{C}$ for $30 \mathrm{~s}$ and extension at $72{ }^{\circ} \mathrm{C}$ for $40 \mathrm{~s}$ with the exception that in the last cycle the extension time was 10 min. The PCR products were visualized by ethidium bromide staining following electrophoresis on $2 \%$ agarose gel (Biorad) in TAE buffer and photographed under UV light.

Two animals of each breed were sequenced. The PCR products amplified by using the standard methods were cut from agarose gel (2\%) and purified using JustSpin Gel Extraction columns (Genaxon). Nucleotide sequencing was carried out according to the dideoxynucleotide chain-termination technique (Sanger et al., 1977) by using a BigDye ${ }^{\mathrm{TM}}$ Terminator v1.1 Ready Reaction cycle sequencing kit and an ABI PRISM 310 nucleotide sequencer (Applied Biosystems).

The 181 animals of the six tested Sudanese camel breeds were genotyped for SNP AJ575419:g.419 $\mathrm{C}>\mathrm{T}$ (intron 1) using the PCR-RFLP method. A 613 bp fragment (primer pair KGH1) covering the sequence containing the mutation site was amplified. The amplicon was digested with MspI restriction endonuclease (Promega) at $37{ }^{\circ} \mathrm{C}$ for four hours to distinguish between the two alleles. For each reaction, $15 \mu \mathrm{L}$ of PCR product, $2 \mu \mathrm{L}$ buffer, $2.5 \mu \mathrm{L} \mathrm{H}_{2} \mathrm{O}$ and $0.05 \mu \mathrm{L}$ enzyme containing 5 units of $M s p I$ were used. The digested fragments (C allele, unrestricted: $613 \mathrm{bp}$; $\mathrm{T}$ allele, restricted: $349 \mathrm{bp}$ and $264 \mathrm{bp}$ ) were analyzed by electrophoresis in $2 \%$ agarose gels, stained with ethidium bromide and photographed under UV light (Figure 1).

A detailed questionnaire survey was designed to obtain information on general characteristics and descriptions of the camel breeds such as body colour, hair length and distribution, hump and udder size.

Chest girth was measured by metric tape immediately behind the breast pad; abdominal girth was determined over the highest part of the hump and the shoulder height was measured for each animal. Weights of animals were then estimated using the Boue formula (1949) as follows:

$$
\mathrm{P}=53 \mathrm{TAH}
$$


Where P is body weight $(\mathrm{kg})$; T chest or heart girth $(\mathrm{cm})$ which was taken immediately behind the chest; An abdominal girth $(\mathrm{cm})$ which taken over the highest part of the hump; and $\mathrm{H}$ is shoulder height $(\mathrm{cm})$.

Genotype and allele frequencies were determined by gene counting. The Chi-square test was employed to evaluate whether the populations were in Hardy-Weinberg equilibrium. However, the t-test was used to determine differences in gene frequencies between populations. The data on the estimation of body weights and phenotypic measurements of the different genotypes were subjected to analysis of variance (ANOVA) using the general linear model (GLM) from the Statistical Analysis Software (SAS Institute Inc., 2000). The statistical model used was:

$$
Y_{i j k l}=\mu+S_{i}+A_{j}+G_{k}+e_{i j k l}
$$

Where $Y_{i j k l}$ is the observation on each trait of the ijklth animal, $\mu$ is the general mean of each trait, $S_{i}$ is the fixed effect of $i$ th sex, $\mathrm{A}_{j}$ is the covariance of $j$ th age, $G_{k}$ is the fixed effect of the $k$ th genotype and eijkl is the random error effect associated to the ijklth observation.

Table 1 The primer sequences, location and size of the amplified fragments

\begin{tabular}{lccl}
\hline Name & $\begin{array}{c}\text { Annealing temperature } \\
\left({ }^{\circ} \mathrm{C}\right)\end{array}$ & $\begin{array}{c}\text { Product size } \\
(\mathrm{bp})\end{array}$ & Sequence $\left(5^{\prime}-3^{\prime}\right)$ \\
\hline KGH1B up & 56 & 508 & $\begin{array}{l}\text { Cagggaccaattccaggat } \\
\text { KGH1B low }\end{array}$ \\
KGH1 up & 51 & 613 & $\begin{array}{l}\text { Ceatccctgaggagcttaca } \\
\text { Gtctgtggacagctcac }\end{array}$ \\
KGH1 low & & & Tgtcctcctcactgcttta \\
KGH2 up & 57 & 671 & Tcaggatgggtgctagtg \\
KGH2 low & & & Tggtgaagacctgctgag \\
KGH3 up & 57 & 687 & Cttctcgctgctgctcatc \\
KGH3 low & & & Gcactggagtggcactttc \\
\hline
\end{tabular}

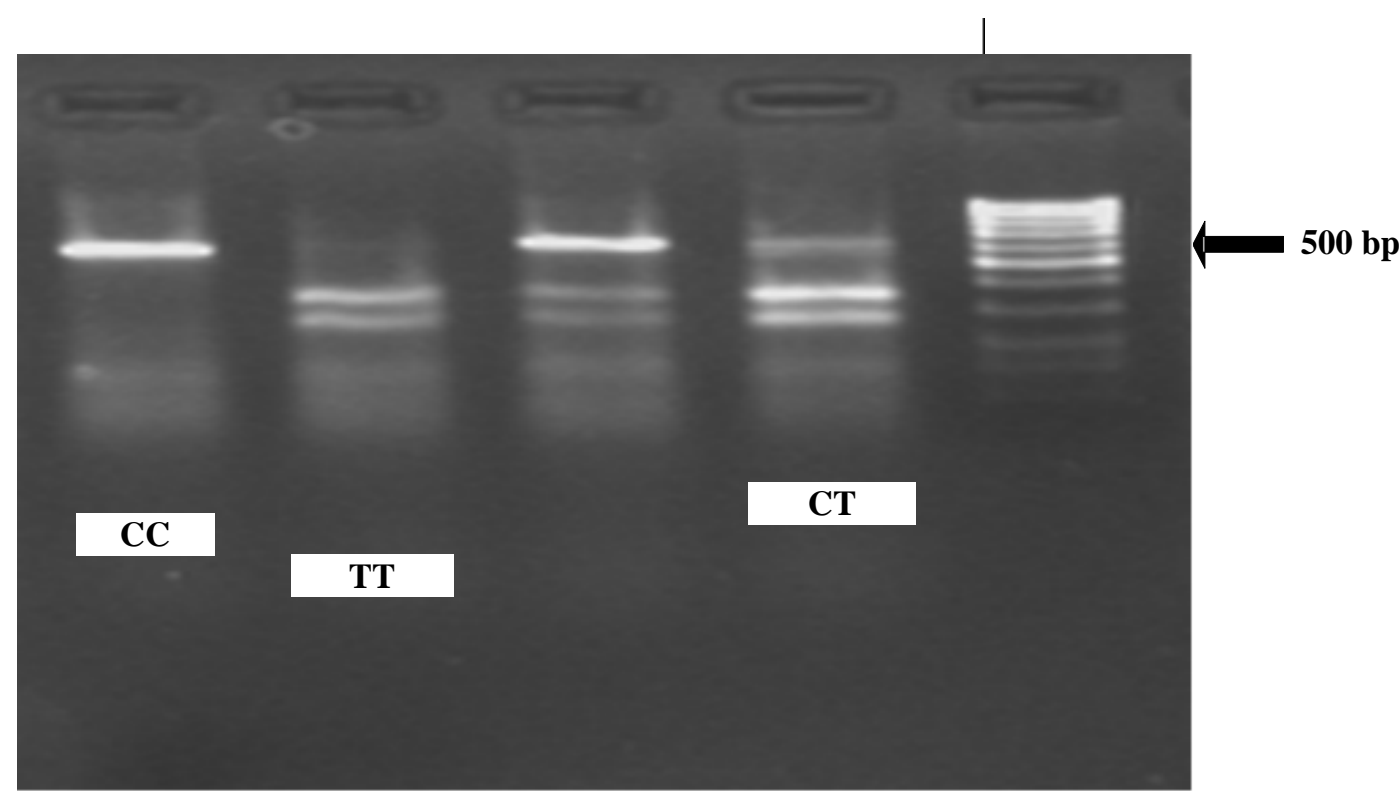

Figure 1 Different genotypes of MspI restriction for SNP g.419 C > T for all studied camel breeds. 


\section{Results}

The nucleotide sequence of the $G H$ gene of Sudanese camels resulted in $1732 \mathrm{bp}$, spanning the region between $-44 \mathrm{bp}$ upstream of the first exon and $+37 \mathrm{bp}$ downstream of the last exon. The sequence comparison of the tested six Sudanese camel breeds GH sequences with the references of GenBank sequence (AJ575419) descending from dromedary camels identified one single nucleotide polymorphism (SNP). The SNP was detected in a non coding region (intron 1) in position g.419C $>$ T relative to the GenBank sequence.

The genotype frequencies of the SNP g.419C $>\mathrm{T}$ in intron 1 in Sudanese camels are listed in Table 2. All camel breeds were found to be carriers of the $\mathrm{T}$ allele with an allelic frequency ranging between 0.30 for the Lahwee breed and 0.57 for the Bishari. The heterozygous (CT) was most frequent among the Rashaidi breed and least frequent among the Kenani breed. The homozygous (TT) had the highest genotype frequency in the Bishari and Anafi breeds, while the homozygous genotype (CC) was most frequent among the Lahwee and Kenani breeds. The chi-square $\left(\chi^{2}\right)$ test showed that each breed was in Hardy-Weinberg equilibrium (HWE) $(\mathrm{P}<0.01)$. Differences in genotypes and alleles frequencies between breeds were tested for significance using the t-test (Table 2). The frequency of the $\mathrm{T}$ allele in the Bishari breed was 0.57, which was significantly $(\mathrm{P}<0.05)$ higher than in all those of other breeds except the Anafi breed.

Table 2 Genotype and allele frequencies of the SNP g.419 C > T in GH gene in Sudanese camel breeds

\begin{tabular}{lccccc}
\hline \multirow{2}{*}{ Breed } & \multicolumn{3}{c}{ Genotypes } & \multicolumn{3}{c}{ Alleles } \\
\cline { 2 - 6 } & $\mathrm{TT}$ & $\mathrm{TC}$ & $\mathrm{CC}$ & $\mathrm{T}$ & $\mathrm{C}$ \\
\hline Kenani & 0.19 & 0.26 & 0.55 & $0.32^{\mathrm{a}}$ & 0.68 \\
Rashaidi & 0.10 & 0.47 & 0.43 & $0.33^{\mathrm{a}}$ & 0.67 \\
Lahwee & 0.17 & 0.27 & 0.57 & $0.30^{\mathrm{a}}$ & 0.70 \\
Anafi & 0.30 & 0.37 & 0.33 & $0.48^{\mathrm{ab}}$ & 0.52 \\
Bishari & 0.37 & 0.40 & 0.23 & $0.57^{\mathrm{b}}$ & 0.43 \\
Kabbashi & 0.13 & 0.40 & 0.47 & $0.33^{\mathrm{a}}$ & 0.67 \\
Overall & 0.21 & 0.36 & 0.43 & 0.39 & 0.61 \\
\hline a,b Within columns allele frequencies with different superscripts differ significantly $(\mathrm{P}>0.05)$.
\end{tabular}

Table 3 points out the phenotypic description of the six camel breeds studied. The results revealed that most ecotypes generally have more or less similar morphological features (grey, brown, yellow colour, large size, heavily built animals with a developed hump) except for the Rashaidi, Anafi and Bishari, which are classified as pack (heavy) camels and called Arabi camels. The Rashaidi camel is also classified as a pack camel but it has different phenotypic characteristics (dark grey, pinkish red colour, light weight and short at shoulders) compared to the other Sudanese pack camels. Moreover, the Rashaidi breed has large size udders and well developed milk veins which may qualify it to be classified as a dairy camel. The results of these phenotypic descriptions also showed that the Anafi and Bishari breeds have similar features (white, yellowish colour and light weight) and are classified as riding camels in Sudan.

The data in Table 4 present the least squares means and standard errors of the abdominal girth, chest girth, shoulder height and body weight. The estimated least squares means of the abdominal girth, chest girth, height at shoulder and body weight were $2.42 \pm 0.02 \mathrm{~m}, 1.97 \pm 0.01 \mathrm{~m}, 1.86 \pm 0.01 \mathrm{~m}$ and $439.05 \pm$ $4.75 \mathrm{~kg}$, respectively. These results (Table 4$)$ indicate that breed had a significant $(\mathrm{P}<0.01)$ influence on all studied traits, while the SNP g.419C $>$ T genotypes had no significant effects $(\mathrm{P}>0.05)$ on those traits. The results also revealed that age of animal significantly $(\mathrm{P}<0.01)$ influenced abdominal girth, chest girth and body weight. Sex had a significant $(\mathrm{P}<0.01)$ effect on chest girth, height at shoulders and body weight. The results also showed that the KEN breed had significantly higher values for chest girth $(2.08 \pm 0.02 \mathrm{~m})$ and body weight $(501.65 \pm 11.79 \mathrm{~kg})$ compared to the other breeds. Male camels had a significantly $(\mathrm{P}<0.05)$ 
greater chest girth, shoulder height and heavier body weight than the corresponding traits of female camels. In addition, the homozygous genotype of the SNP g.419 (TT) had the highest, but not significantly different ( $\mathrm{P}>0.05$ ) abdominal girth, chest girth, height at shoulders and body weight; followed by those of the heterozygous (TC), while the homozygous (CC) had the lowest values.

Table 3 Phenotypic descriptions of the Kenana, Kabbashi, Rashaidi, Lahawee, Anafi and Bishari camel breeds in the Sudan

\begin{tabular}{|c|c|c|c|c|c|c|}
\hline \multirow{2}{*}{ Characteristics } & \multicolumn{6}{|c|}{ Breed } \\
\hline & Kenani & Kabbashi & Rashaidi & Lahawee & Anafi & Bishari \\
\hline Body colour & $\begin{array}{l}\text { Dark brown, } \\
\text { grey }\end{array}$ & $\begin{array}{l}\text { Red, grey, } \\
\text { yellow }\end{array}$ & $\begin{array}{l}\text { Reddish, } \\
\text { dark grey }\end{array}$ & $\begin{array}{l}\text { Red, brown, } \\
\text { yellowish }\end{array}$ & $\begin{array}{l}\text { White, } \\
\text { yellowish }\end{array}$ & White \\
\hline Colour pattern & Uniform & Uniform & Uniform & Uniform & Uniform & Uniform \\
\hline Hair length & Medium, long & $\begin{array}{l}\text { Medium, } \\
\text { long }\end{array}$ & $\begin{array}{l}\text { Short, } \\
\text { medium }\end{array}$ & Medium & Short & Short \\
\hline $\begin{array}{l}\text { Wool } \\
\text { distribution }\end{array}$ & Whole body & $\begin{array}{l}\text { Whole } \\
\text { body }\end{array}$ & $\begin{array}{l}\text { Whole } \\
\text { body }\end{array}$ & Whole body & Whole body & Whole body \\
\hline Face profile & Flat & Flat & Flat & Convex & Flat & Concave \\
\hline Rump profile & Roomy & Flat & Flat & Sloping & Flat & Flat \\
\hline Hump size & Large, medium & Small & $\begin{array}{l}\text { Small, } \\
\text { medium }\end{array}$ & Large & Small & $\begin{array}{l}\text { Small, } \\
\text { medium }\end{array}$ \\
\hline $\begin{array}{l}\text { Hump } \\
\text { orientation }\end{array}$ & Erect & Erect & Erect & $\begin{array}{l}\text { Erect, bent } \\
\text { sideways }\end{array}$ & Erect & Erect \\
\hline Hump location & $\begin{array}{l}\text { Middle, to the } \\
\text { back }\end{array}$ & Middle & Middle & Middle & $\begin{array}{l}\text { Middle, to the } \\
\text { back }\end{array}$ & Middle \\
\hline Ears size & Large & Medium & Large & Large & Large & Medium \\
\hline Ears orientation & Erect & Erect & Backward & Erect & Forward & $\begin{array}{l}\text { Backward, } \\
\text { erect }\end{array}$ \\
\hline Tail base & Thick & Thin & Thin & Thick & Thin & Thin \\
\hline Tail length & Long & $\begin{array}{l}\text { Short, } \\
\text { medium }\end{array}$ & Medium & Medium & Long & Long \\
\hline Udder size & Large, medium & Medium & Large & Medium, large & Rudimentary & Rudimentary \\
\hline Teat size & Large, medium & Medium & Large & Medium, large & Rudimentary & Rudimentary \\
\hline
\end{tabular}

\section{Discussion}

The $G H$ sequences of the six tested Sudanese camel breeds were aligned and compared with the GenBank camel GH sequence AJ575419. Only one SNP was identified in a non coding region (intron 1) in position AJ575419:g.419C $>$ T. It is noteworthy to state that numerous mutations in this gene were documented in other species, viz. in cattle more than 10 SNPs have been recorded (Chikuni et al., 1994; Ge et al., 2003; Musa, 2007). Also, many SNPs have been reported in sheep (Bastos et al., 2001). Neelam Gupta et al. (2007) found several SNPs in the growth hormone gene of Black Bengal goats. The lack of SNPs in $G H$ of Sudanese camels may be due to the probability that all these ecotypes may have originated from the same stock and not enough time has passed for segregation and generation of new mutants. The detected SNP in the GH gene of Sudanese camel was previously reported in Pakistani dromedary camels (Shah, 2006).

The Anafi and Bishari breeds tended to have a higher $\mathrm{T}$ allele frequency compared to those of the other four breeds. However, the difference in the $\mathrm{T}$ allele frequency was significant only between Bishari and the other four breeds. The Anafi and Bishari breeds have the same morphological appearance (white coat and relatively light weight), and both are classified as riding camels. This SNP is only one of a large probable number of mutations in the whole genome but it is possible that the higher T allele frequency in Anafi and Bishari is the result of a probable similar ancestral origin. However, these suggestions require extensive 
studies to verify them. Other breeds (Kenani, Lahwee, Rashaidi and Kabbashi) have higher body weights and are classified as pack camels (draught animals). Generally they have almost similar $\mathrm{T}$ allele frequencies (0.30 to 0.33$)$.

The results of phenotypic descriptions showed that the Rashaidi breed has large size udders and well developed milk vein which may qualify it to be classified as a dairy camel. These findings are similar to those reported by Wardeh (2004). Regarding the udder and teats feature, Kenani, Kabashi and Lahwee camels have well developed udders (medium to large size). This probably explains their capacity in milk production and may be classified as dual purpose (beef and dairy) camels.

Table 4 Least square means and standard errors of abdominal girth (AG), chest girth (CG), shoulder height (SH) and body weight (BW)

\begin{tabular}{|c|c|c|c|c|c|}
\hline Parameter & No. & $\begin{array}{c}\mathrm{AG}(\mathrm{m}) \\
\text { Mean } \pm \text { s.e. }\end{array}$ & $\begin{array}{c}C G(\mathrm{~m}) \\
\text { Mean } \pm \text { s.e. }\end{array}$ & $\begin{array}{c}\text { SH }(\mathrm{m}) \\
\text { Mean } \pm \text { s.e. }\end{array}$ & $\begin{array}{c}\mathrm{BW}(\mathrm{kg}) \\
\text { Mean } \pm \text { s.e. }\end{array}$ \\
\hline Age group & & $* *$ & $* *$ & NS & $* *$ \\
\hline $4-6$ years & 56 & $2.31 \pm 0.03$ & $1.92 \pm 0.01$ & $1.85 \pm 0.01$ & $404.36 \pm 6.86$ \\
\hline 7 - 9 years & 61 & $2.49^{b} \pm 0.03$ & $2.02^{\mathrm{b}} \pm 0.01$ & $1.89^{\mathrm{a}} \pm 0.01$ & $470.98^{b} \pm 7.23$ \\
\hline $10-12$ years & 43 & $2.49^{b} \pm 0.04$ & $2.02^{b} \pm 0.01$ & $1.87^{\mathrm{a}} \pm 0.01$ & $465.14^{b} \pm 8.97$ \\
\hline$\geq 13$ years & 21 & $2.47^{b} \pm 0.05$ & $2.01^{\mathrm{b}} \pm 0.02$ & $1.89^{\mathrm{a}} \pm 0.02$ & $464.22^{b} \pm 12.82$ \\
\hline Breed & & $* *$ & $* *$ & $* *$ & $* *$ \\
\hline Kenani & 31 & $2.51^{b} \pm 0.04$ & $2.08^{b} \pm 0.02$ & $1.95^{\mathrm{c}} \pm 0.01$ & $501.65^{b} \pm 11.79$ \\
\hline Rashaidi & 30 & $2.58^{\mathrm{b}} \pm 0.04$ & $1.96^{\mathrm{a}} \pm 0.02$ & $1.78^{\mathrm{a}} \pm 0.01$ & $439.10^{a} \pm 12.76$ \\
\hline Lahwee & 30 & $2.50^{\mathrm{b}} \pm 0.04$ & $1.99^{\mathrm{a}} \pm 0.02$ & $1.86^{\mathrm{bc}} \pm 0.01$ & $452.48^{\mathrm{a}} \pm 12.62$ \\
\hline Anafi & 30 & $2.40^{\mathrm{b}} \pm 0.04$ & $1.96^{\mathrm{a}} \pm 0.02$ & $1.86^{\mathrm{b}} \pm 0.01$ & $424.83^{\mathrm{a}} \pm 11.94$ \\
\hline Bishari & 30 & $2.38^{\mathrm{ab}} \pm 0.04$ & $1.97^{\mathrm{a}} \pm 0.02$ & $1.86^{\mathrm{b}} \pm 0.01$ & $424.37^{\mathrm{a}} \pm 12.34$ \\
\hline Kabbashi & 30 & $2.23^{\mathrm{a}} \pm 0.04$ & $1.97^{\mathrm{a}} \pm 0.02$ & $1.92^{\mathrm{c}} \pm 0.01$ & $450.67^{\mathrm{a}} \pm 11.95$ \\
\hline Sex & & NS & $* *$ & $* *$ & $* *$ \\
\hline Female & 131 & $2.43 \pm 0.02$ & $1.96 \pm 0.01$ & $1.84 \pm 0.01$ & $432.02 \pm 6.00$ \\
\hline Male & 50 & $2.44^{\mathrm{a}} \pm 0.03$ & $2.02^{b} \pm 0.01$ & $1.91^{\mathrm{b}} \pm 0.01$ & $465.68^{b} \pm 9.60$ \\
\hline SNPg.419C $>$ T & & NS & NS & NS & NS \\
\hline $\mathrm{TT}$ & 38 & $2.48 \pm 0.03$ & $2.01 \pm 0.02$ & $1.88 \pm 0.01$ & $463.21 \pm 10.78$ \\
\hline $\mathrm{TC}$ & 65 & $2.43 \pm 0.03$ & $1.97 \pm 0.01$ & $1.87 \pm 0.01$ & $442.87 \pm 8.43$ \\
\hline $\mathrm{CC}$ & 78 & $2.40 \pm 0.03$ & $1.99 \pm 0.01$ & $1.87 \pm 0.01$ & $440.48 \pm 7.86$ \\
\hline Overall mean & & $2.42 \pm 0.02$ & $1.97 \pm 0.01$ & $1.86 \pm 0.01$ & $439.05 \pm 4.75$ \\
\hline
\end{tabular}

** Significant at $\mathrm{P}<0.01$; NS not significant at $\mathrm{P}>0.05$.

${ }^{\mathrm{a}, \mathrm{b}, \mathrm{c}}$ Within rows means with different superscripts differ significantly at $\mathrm{P}<0.05$.

The body weights obtained in this study for the Bishari and Anafi breeds are in agreement with the findings of Wardeh (1989), Khouri (2000) and Wardeh (2004). Male camels had significantly higher body measurements than the females, which was similar to that reported by Dioli et al. (1992) and Mehari et al. (2007) who stated that there is quite distinctive sexual dimorphism in camels, i.e. the male camels is usually taller and of heavier weight than the females. These differences in tested traits between male and female camels may reflect differences in the hormonal secretions and their activities in the two sexes. 
The age group, 7 to 9 years, had significantly higher values of the studied traits, followed by those of the age group 10 to 12 years, then those of the age group $\geq 13$ years. However, the age group 4 to 6 years had significantly lower values of tested traits than those of the other age groups. This means that camels reach maturity (growth peak) within 7 to 9 years of age; after which the different measurements decline. This trend is reflected in the growth curve of the Sudanese camels.

An association was indicated between $G H$ polymorphism and carcass characteristics in cattle (Ardiyanti et al., 2009). However, the evidence obtained from this study does not support the presence of any association between body measurements and $G H$ polymorphism.

\section{Conclusion}

The Dromedary camel contributes significantly to family food security in semi dry and dry climates, and is a major component of the agro-pastoral systems in vast pastoral areas in Asia and Africa. This study demonstrated that only one single nucleotide polymorphism was detected in the growth hormone gene of the studied Sudanese camel breeds after sequencing. Though it is located in a non coding region (intron 1), it can be used as a genetic marker in different genetic studies, e.g. to determine genetic relationships and to establish the phylogenic tree for different camel breeds. This study showed that there were no associations between growth hormone genotypes and body measurements. Further research and more studies with larger numbers of animals are required to investigate these associations between growth hormone genotypes and camel body measurements.

\section{Acknowledgement}

Great appreciation is expressed to the staff of the laboratory of Breeding Biology and Molecular Genetics, Faculty of Agriculture and Horticulture, Humboldt University of Berlin. Appreciation is also expressed to the Ministry of Higher Education (Republic of Sudan) for the financial support of part of this work. My special thanks go to the German Academic Exchange Service (DAAD) for helping me to stay in Berlin.

\section{References}

Agab, H., 1993. Epidemology of camel diseases in eastern Sudan with emphasis on brucellosis. M.V.Sc. thesis, Faculty of Veterinary Medicine, University of Khartoum, Sudan.

Ardiyanti, A., Oki, Y., Suda, Y., Suzuki, K., Chikuni, K., Obara, Y. \& Katoh, K., 2009. Effects of GH gene polymorphism and sex on carcass traits and fatty acid compositions in Japanese Black cattle. Anim. Sci. J. 80, 62-69.

Bastos, E., Cravador, A., Azevedo, J. \& Guedes-Pinto, H., 2001. Single strand conformation polymorphism (SSCP) detection in six genes in Portuguese indigenous sheep breed "Churra da Terra Quente". Biotechnol. Agron. Soc. Environ.5, 7-15.

Boue, A., 1949. Weight determination in the North African Dromedary. Rev. Elev. Vet. Pays trop. N.S. 3, 13-16.

Chikuni, K., Nagatsuma, T., Tabata, T., Monma, M., Ozawa, S. \& Ozutsumi, K., 1994. Genetic variants of the growth hormone gene in Japanese cattle. Anim. Sci. Technol. 65, 340-346.

Ge, W., Davis, M.E., Hines, H.C., Irvin, K.M. \& Simmen R.C.M., 2003. Association of single nucleotide polymorphisms in the growth hormone and growth hormone receptor genes with blood serum insulinlike growth factor I concentration and growth traits in Angus cattle. J. Anim. Sci. 81, 641-648.

Hua, G.H., Chen, S.L., Yu ,J.N., Cai, K.L., Wu, C.J., Li, Q.L., Zhang, C.Y., Liang, A.X., Han, L., Geng, L.Y., Shen, Z., Xu, D.Q. \& Yang, L.G., 2009. Polymorphism of the growth hormone gene and its association with growth traits in Boer goat bucks. Meat Sci. 81, 391-395.

Khouri, F., 2000. Camel in Sudan: Ecology, production systems, characterization and herd dynamics. The Camel Applied Research and Development Network (CARDN). The Arab Center for Studies of Arid Zones and Dry Land (ACSAD). CARDN/ACSAD/ Camel/ P 96/ 2000. 137 pp.

Liu, Y.F., Zan, L.S., Li, K., Zhao, S.P., Xin, Y.P., Lin, Q., Tian, W.Q. \& Wang, Z.W., 2010. A novel polymorphism of GDF5 gene and its association with body measurement traits in Bos taurus and Bos indicus breeds. Mol. Biol. Reports 37, 429-434. 
Lucy, M.H., Hauser, S.D., Eppard, P.J., Krivi, G.G. \& Collier, R.J., 1991. Genetic polymorphism within the bovine somatotropin (bST) gene detected by polymerase chain reaction and endonuclease digestion. J. Dairy Sci. 74 (Suppl. 1), 284 (Abstract).

Maniou, Z., Wallis, O.C., Sami, A.J. \& Wallis, M., 2001. Molecular evolution of growth hormone in cetrartiodactyla. http://www.endocrine-abstracts.org/ea/0002/ ea0002p58.htm.

Mehari, Y., Mekuriaw, Z. \& Gebru, G., 2007. Potentials of camel production in Babilie and Kebribeyah woredas of the Jijiga Zone, Somali Region, Ethiopia. Livestock Research for Rural Development. $19,4$.

Ministry of Animal Resources, 2006. Department of Statistics and Information, Khartoum-Sudan.

Musa, L.M-A., 2007. Characterization and utilization of dairy cattle in Sudan. PhD thesis. HumboldtUniversitat zu Berlin, Germany.

Neelam Gupta, N., Ahlawat, S.P.S., Kumar, D., Gupta, S.C., Alok Pandey \& Geetu Malik, 2007. Single nucleotide polymorphism in growth hormone gene exon-4 and exon-5 using PCR-SSCP in Black Bengal goats - A prolific meat breed of India. Meat Sci. 76, 658-665.

Sanger, F., Nicklen, S. \& Coulson, A.R., 1977. DNA sequencing with chain terminating inhibitors. Proc. Natl. Acad. Sci. U.S.A. 74, 5463-5467.

SAS, 2000. Statistical Analysis Software (CD-ROM), Version 8.1, SAS Institute Inc., Cary, N.C., USA.

Schlee, P., Graml, R., Rottmann, O. \& Pirchner, F., 1994. Influence of growth hormone genotypes on breeding values of Simmental bulls. J. Anim. Breed. Genet. 111, 253-256.

Schwartz, H.J. \& Dioli, M., 1992. The one-humped camel in Eastern Africa. A pictorial guide to diseases, health care and management. Verlag Josef Margraf, Germany.

Shah, M.G., 2006. Differentiation of six Pakistani camel breed by phenotype and molecular genetics analysis. $\mathrm{PhD}$ thesis, University of Agriculture, Faisalabad, Pakistan.

Sodhi, M., Mukesh, M., Prakash, B., Mishra, B.P., Sobti, R.C., Karn Singh, P., Singh, S. \& Ahlawat, S.P.S., 2007. MspI allelic pattern of bovine growth hormone gene in Indian Zebu cattle (Bos indicus) breeds. Biochem. Genet. 45, 145-153.

Wallis, M., Lioupis, A. \& Wallis, O.C., 1998. Duplicate growth hormone genes in sheep and goat. J. Mol. Endocrin. 21, 1-5.

Wardeh, M.F., 1989. Arabian Camels: Origin, Breeds and Husbandry. Al-Mallah Publ., Damascus. 500 pp. (Arabic).

Wardeh, M.F., 2004. Classification of the dromedary camels. J. Camel Sci. 1, 1-7. 